\title{
Applied Bachelor Degree Programme as the Direction of Mobile Social Teachers Training in the Conditions of Professional and Mobile Practice
}

\author{
Rinad H. Iskhakov ${ }^{1 *}$, Marina V. Sturikova ${ }^{1}$, Irina O. Dercach ${ }^{1}$, Svetlana V. Smirnova ${ }^{1}$ \\ Vasily I. Miroshnichenko ${ }^{2}$, Laysan A. Ribakova ${ }^{3}$ \\ ${ }^{1}$ Russian State Vocational Pedagogical University, Ekaterinburg, RUSSIA \\ ${ }^{2}$ Ural State Medical University, Ekaterinburg, RUSSIA \\ ${ }^{3}$ Kazan (Volga region) Federal University, Kazan, RUSSIA
}

Received 22 July 2018 - Revised 10 November 2018 - Accepted 3 December 2018

\begin{abstract}
The relevance is caused by the need to train mobile social teachers with a high level of adaptation to the changing working conditions and capable timely, reasonably, optimally and quickly to solve social and pedagogical problems of people of different age and social categories. The purpose of the article is in defining the role of applied bachelor degree in training of mobile social teachers in the conditions of professional - mobile practice. The leading method is comparative analysis of social teachers training in the conditions of state educational standard of 2005 and new generation standard FGOS-2010. The article presents the method of projects as the leading kind of activity of practice-oriented training in the direction of applied bachelor degree of future social teachers in the conditions of practice. The method of project activity can be realized in training of specialists in different direction of training and profile.
\end{abstract}

Keywords: mobility, applied bachelor degree, professional mobility, professional and mobile practice, project activity, social teacher

\section{INTRODUCTION}

Training of practice-oriented specialists reflects the need of modern world market of work for specialists with high ability of adaptation to working conditions, with the created applied knowledge, skills, possessing certain types of professional activity, the ability to solve efficiently production problems on the basis of all-professional and professional competences and professional-personal qualities (Reid-Griffin \& Slaten, 2016).

This direction in development of professional education in Russia is reflected in the Resolution of the Government of the Russian Federation dd. 01.01.01 N 667 (with alterations dd. June 30, 2010) “On carrying out the experiment on creation of an applied bachelor degree in educational institutions of secondary professional education and higher professional education" (The resolution of the Government of the Russian Federation, 2016).

The experiment on an applied bachelor degree was made under the direction of the Ministry of Education and Science of the Russian Federation in 7 educational institutions of higher professional education and 23 educational institutions of secondary professional education within 4 years.

In the course of scientific discussion, it was defined that, in the most general view, the applied bachelor degree means increasing hours of practical work by means of decreasing of scientific-theoretical questions.

During transition in Russia to new generation of state standards updating of applied bachelor degree happens in all directions and profiles of vocational training, in particular, as well as pedagogical education (Efimovam, 2017).

(C) 2019 by the authors; licensee Modestum Ltd., UK. This article is an open access article distributed under the terms and conditions of the Creative Commons Attribution License (http://creativecommons.org/licenses/by/4.0/). $\square$ rinad.isxakov@mail.ru (*Correspondence) $\square$ sturikova_marina@mail.ru $\square$ ioderkach@mail.ru 


\section{Contribution of this paper to the literature}

- The authors explain the significance of practice-oriented training of social work specialists with high level of adaptation to working conditions, with developed applied knowledge, skills, and competencies, including the competencies of specific types of professional activity, with ability to solve industry tasks effectively, basing on the general and professional competencies, and on such professional and personal skill as mobility.

- The article defines the practice-oriented training of specialists to be successfully implemented in the conditions of professionally mobile practice, which contributes to the development of general and professional competencies and such professional and personal skill as professional mobility.

- The authors presented the key concepts of professional mobility of bachelor - a future social work teacher - and defined professional and mobile practice in the conditions necessary for bachelors' formation.

- The results of the conducted research identify the effectiveness of professional and mobile practice as a type practice-oriented training of bachelors, future social work teachers with such developed professional and personal skill as professional mobility, which allows them promptly solve social and pedagogical problems working with people of different ages and social categories, who have difficult life situations and ask a social organization for help.

The applied bachelor degree in the direction "Pedagogical education" and "Psychology and pedagogical education" (the Ministry of Education and Science of the Russian Federation of December 22, 2009 No. 788., 2009) training is focused on mastering by students a broad set of competences in such areas as education, culture and social sphere. The expert has to be trained for pedagogical, social, research and cultural and educational activity (Zeer, Lebedeva \& Zinnatova, 2016).

Emphasis on practice-oriented training of social teachers is caused by the following circumstances:

- first, in the conditions of rising of social tension in the society and the state connected with the emergence of new social challenges: the increasing flow of migrants, the increasing level of people with HIV/AIDS, new forms of addiction, deviations, delinkventions, youth extremism, high level of unemployment, the increasing number of solo parent families etc. - there appears a sharp need for the operational solution of these social problems;

- secondly, due to transformation of these social challenges in social and pedagogical context of life and inadmissibility of their further aggravation;

- thirdly, due to dynamic rooting of social and pedagogical problems in the conditions of educational organizations among students and the need to preserve successful socialization of this category;

- fourthly, due the increased number of addresses from the population according to the solution of social and pedagogical problems there is a production need for the mobile solution of these problems;

- fifthly, the mobility of the solution of these problems in the conditions of educational and social organizations, perhaps, in the presence of such formed professional - personal quality as professional mobility with experts - teachers, social teachers and training of these experts in the conditions of professional educational organizations of different types.

These circumstances are a basis in the development of the theory and practice of social pedagogics and also factors in the practice-oriented training of future social teachers.

\section{LITERATURE REVIEW}

Over the last years the theoretical-methodological bases of social pedagogics are developed (Gimaliev et al., 2018; Lavrentyeva, 2014); the technique and technology of social teachers' work at various institutions (Mardakhayev, 2013); manuals for vocational training of social teachers are published (Akishina et al., 2017; Galaguzova, 2016; Mutavchi et al., 2018).

Irrespective of a conjuncture of labor market and tendencies of development of the system of professional education the social teacher in work meets with various traditional and brand new deviations of teenagers and in this regard he is top requested as a HR specialist in educational and social institutions. To work successfully in different types of institutions he has to be mobile.

A social teacher has to be professionally mobile to adapt actively in the changing conditions of professional work and timely, expedient, optimal and quickly solve a great variety of social and pedagogical problems (Gluzman, 2017). 
The mobility of a bachelor - future social teacher is an important qualitative characteristic of his vocational training. It provides not only successful adaptation of university graduates to labor market, but promotes their adaptation to the changing conditions in professional activity, self-realization and professional self-development (Morozova \& Symanyuk, 2012).

The problem of mobility is rather widely covered by domestic and foreign scientists - philosophers, sociologists, psychologists, teachers, economists. The founder of this direction abroad is Sorokin (1991).

The mobility in pedagogics is reflected in works by Kugel (1983), Moryleva (2001), Novikov (2001), Arkhangelskii (2003), Kalinovsky (2011), Amirova (2009), Vasilenko (1996), Goryunova (2006), Igoshev (2008), Kipina (2009).

The applied bachelor degree can be one of the ways of the formation of professional mobility of bachelors. The applied bachelor degree is shown in the practice-oriented approach in training of specialists with new professional and personal qualities.

Many psychology-pedagogical works are devoted to problems of student teaching of students, namely by Gudzenko (1987), Slastenin (1995), Conics (1997), Galaguzova (2016), Kovalyova (2001), Drozdova (2003), Korotkov (2004), Zonina (2009), Kondrachuk (2008), Dzodziev (2009), Davydova et al. (2016), Evtodieva et al. (2016), Davydova, Dorozhkin \& Fedorov (2018). At the same time, the theory and practice of professional mobility of bachelors - future social teachers are obviously studied insufficiently.

In the works studied by us the question on mobility formation at bachelors in practice intentionally was not considered. That is why there are a number of contradictions:

- social - pedagogical - between the increasing requirements to the person due to dynamic reforming of the Russian system of social protection and discrepancy to these requirements of the level of professional mobility development as professionally important quality at bachelors - future social teachers;

- scientific- pedagogical - between the need of professional mobility formation at students and the existing theoretical-methodological bases not allowing to solve this problem in the conditions of practice;

- scientific - methodical - between the demand of the system of professional and mobile practice of bachelors and the lack of its conceptual justification in the theory and the technique of professional education.

On the basis of our experiment- search activity we defined that effectiveness of mobility formation of bachelors of psychology-pedagogical education is possible in the conditions of professional -mobile practice.

Scientific - methodological creation of the concept of this practice was carried out on the basis of the following definitions:

- professional mobility of a social teacher is an integral dynamic quality of a person causing success of its adaptation to the changing conditions of professional activity, readiness for self-improvement, selfdevelopment and realization in professional community, including the system of administrative, communicative and research competences;

- professional-mobile practice represents a type of the practice-oriented educational activities for a professional becoming of students in working conditions for the purpose of acquisition and possession of professional competences: administrative, communicative and research.

For targeted formation of social teacher professional mobility in the conditions of professional and mobile practice the following methodological approaches have conceptual value:

- creation of the system uniting all types practices as the components of professional education (systems approach) in one complete unity;

- formation of the contents of working programs of all types of practices, including theoretical, research, scientific- methodical, organizational -informational and control-evaluating components aimed at the formation of all-professional, professional competences (competence-based approach);

- orientation of the practice -oriented process to the formation at all the education participants of the semantic notions and systems of values meeting the requirements of such socially important activity as social pedagogical activity to assist people of different age and social groups who appeared in a difficult life situation (axiological approach);

- creation of variable educational and professional tasks for the trainee to solve various social and pedagogical problems at people of different age and social groups, contributing to formation and development of operational and divergent thinking (activity approach). 
Thus, professional and mobile practice in this work is understood as a type of the practice-oriented educational activities for professional becoming of students in working conditions for the purpose of formation of professional competences and such a professional-personal quality as professional mobility.

\section{RESULTS}

\section{Stages of Concept Introduction}

Introduction of this concept assumes carrying out the following stages of experimental work:

- definition of initial level of professional mobility formation at students before professional- mobile practice on the basis of self-inspection method;

- development and deployment of scientific- methodological support of professional - mobile practice promoting successful formation of professional mobility at students in the conditions of social organizations during practice;

- determination of the level and identification of dynamics of professional mobility formation at students future social teachers during all years of studying at higher education institution.

\section{Ascertaining Experiment}

803 students participated in the experiment: 746 students of the specialty05071165 Social pedagogics (031300), specialization "Social management in education system" (031325); 57 students of training direction 44.03.02 (050400.62) Psychology- pedagogical education of training profile "Psychology and social pedagogics.

The experiment consists of two temporary periods connected with the realization of GOS (State Educational Standard) - 2005 and state standards of new generation (FGOS-Federal Educational Standard)

The period of the experiment in the conditions of GOS realization - 2005 is the period since $2006-2015$. The students studying at specialty 05071165 Social pedagogics (031300), specialization "Social management in education system" (031325) participated in it. During this period the organization and content of training the students had professional approach.

Since 2012 - 2016 is the period of the experiment in the conditions of realization of new generation standard (FGOS-Federal Educational Standard). The students studying in the training direction 44.03 .02 (050400.62) Psychological- pedagogical formation of training profile "Psychology and social pedagogics" participated in it. During this period the organization and content of students training had professional and mobile approach.

Professional-applied competences which were included in the blocks of all-professional competences were the criterion of professional mobility formation: administrative, communicative, research.

The administrative block included organizational, documentary support and normative-legal professionallyapplied competences.

The communicative block included communicative and consulting-informational professionally-applied competences

The research block included scientific-methodical and project professionally-applied competences.

All professionally-applied competences are differentiated on three levels: cognitive (competence-based), affective (axiological) and conative (activity).

Monitoring was implemented on the basis of self-examination method, through filling in by the students of a self-examination questionnaire before practice and after practice during all types of practice for the entire period of training in higher education institution according to ten-point scale.

Analytic-diagnostic task was the comparison of results of professional mobility formation in the conditions of GOS-2005 and FGOS-2010.

In ascertaining experiment, we compared two periods: GOS-2005 and FGOS-2010 - the degree of formation of professional and applied competences at first-year students after their first practice, namely educational one (Figure 1). 


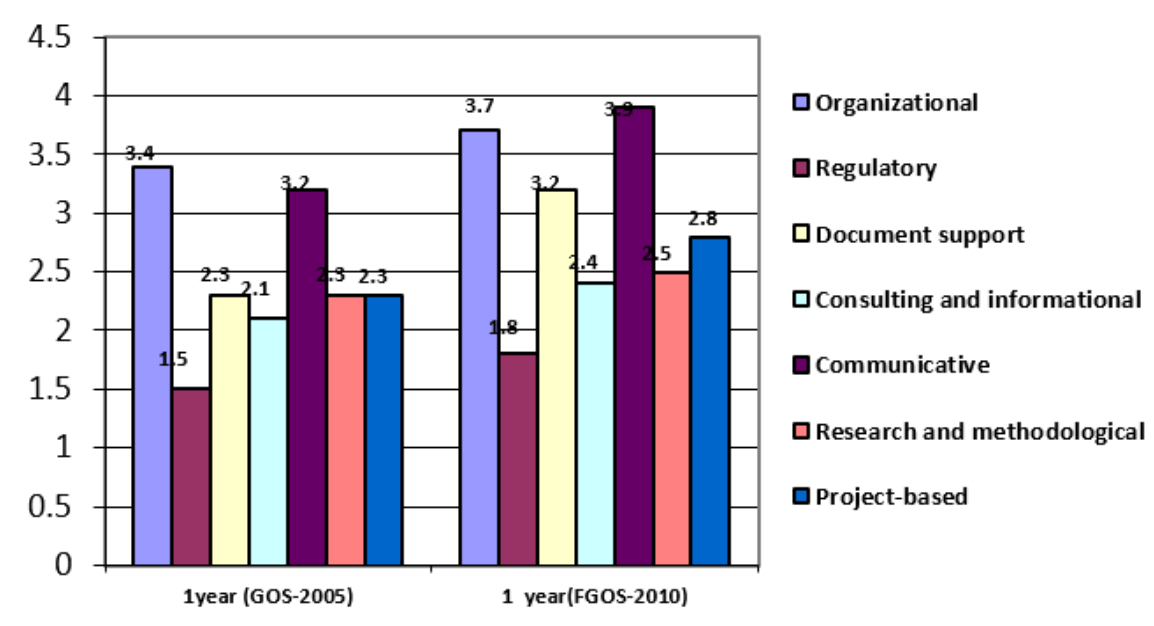

Figure 1. Distribution of professional mobility formation degree at students of 1 st year

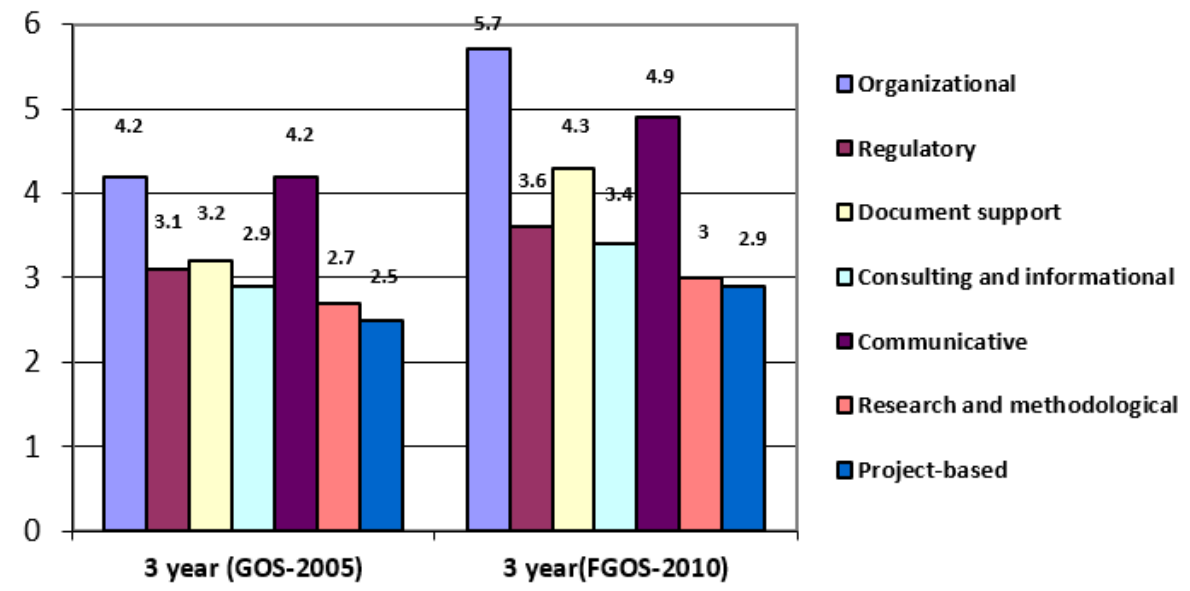

Figure 2. Distribution of professional mobility formation degree at students of 3rd year

When analyzing the received data, we can see that the degree of formation of such professional and applied competences as organizational and communicative ones were initially high in the respect to the formation degrees of other competences. It is observed in both periods (GOS-2005 and FGOS-2010). We associate it with the fact that these competences at students were created prior to higher education institution in the conditions of the school period of teaching. Students came to higher education institution with certain levels of formation of these competences.

\section{Formative Experiment}

In formative experiment we compared two periods: GOS-2005 and FGOS-2010 - degree of professional and applied competences formation at third-year students after their third practice - social - pedagogical (Figure 2).

When analyzing the received data, we can see that the formation degree of such professional competences as normative-legal, document support, consulting- informational were initially not at a high level and according the dynamics of formation and development lagged behind such professional competences as organizationalcommunicative in the respect to the formation degrees of other competences. It is observed in both periods. We associate it with the fact that these competences were new for students and were to undertake the stages of formation, development, possession, and these professional- applied competences became acquired.

\section{Formative Experiment}

In spite of the fact that pedagogical conditions on the organizing and carrying out professional or professionalmobile practice, that is in the conditions of every period, were organizational- meaningfully identical as the requirement of scientific approach for realization of experimental and searching activity, nevertheless there were 


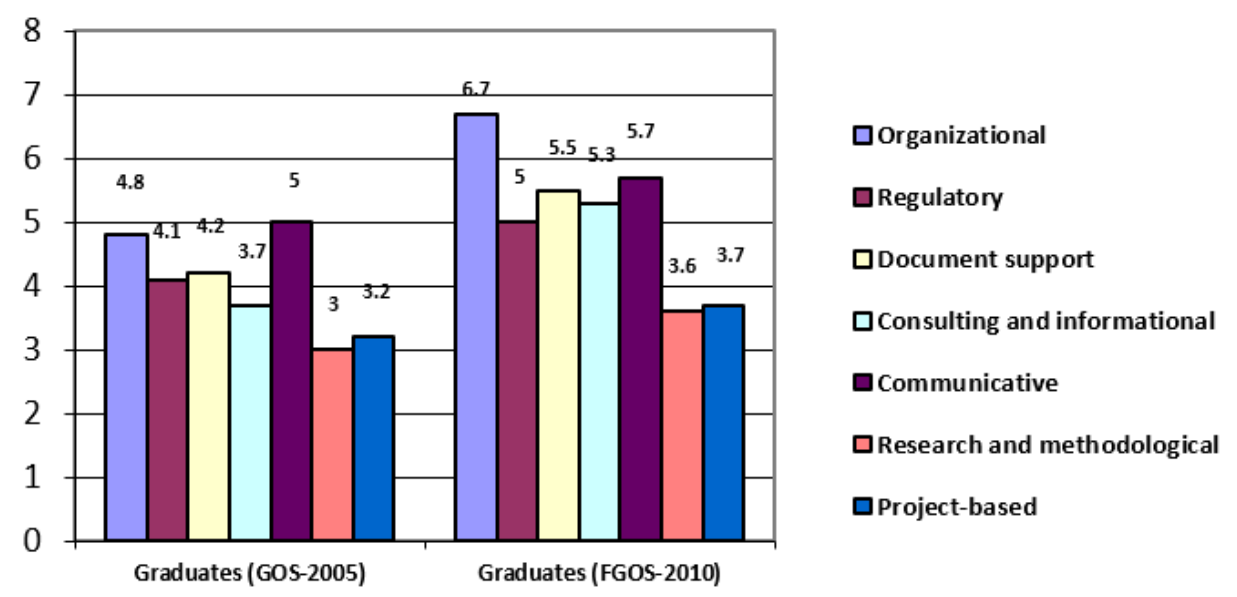

Figure 3. Formation degree distribution of professional mobility at graduates

differences in statistical data on the level of formation degree of these or those competences. It was caused by the objective and subjective reasons, not dependent on requirements of the experiment, namely:

- formation degree of theoretical readiness of the practice teacher to realize these or those professional and educational tasks in the conditions of practice. In its turn it is caused by the following factors: with a personal responsible attitude of the student to the professional becoming which is seen in the degree of his learning ability and proficiency; in degree of being brought up and good breeding; with the level of subject teaching directed to the formation of these or those competences; with non-correlation of the time of subject studying directed to the formation of these or those competences with professional-educational requirements set by the purpose and tasks of practice;

- working conditions of the organizing and carrying out practice which were provided by this or that institution for realizing this or that type of practice. Optimality of working conditions depended factorial on:

- social orientation of this organization for the solution of social and pedagogical problems at people of different age groups and social category got into a difficult life situation;

- the level of professional competence;

- preparedness and readiness of the employee of the organization to render assistance to practice teacher to perform his professional and educational tasks of practice program aimed at the formation, development and mastering these or those professional competences;

- practice teacher' involvement into the variety of solutions of social and pedagogical problems at people of different age groups and social category of people got into a difficult life situation;

- optimal realizing of system and systematic feed-back between the practice head from the releasing department, with the methodologist from the organization and the practice teacher himself.

These revealed factors did not affect the success of organizing and carrying out the experiment on realizing a new approach of professional and mobile practice realization. It allowed revealing a positive tendency regarding dynamic formation, development and mastering of professional-applied competences during work practice in the conditions of social organizations of various departmental affiliation.

Thus, as a result of the completing control experiment positive tendencies in the development of all studied professional-applied competences are registered, it means that the experiment confirmed the significance of allocated pedagogical conditions of effectiveness increase of practice realization (Figure 3 ).

We observe more active positive dynamics in formation of professional-applied competences as a basis of such an integral quality of professional mobility in the conditions of professional-mobile approach in organizing the practice.

The results of the experiment confirmed the effectiveness of applying the approach on organizing and conducting professional- mobile practice This approach allowed to increase positive dynamics of changes of such professional - applied competences as organizational, normative-legal, document support, consultinginformational, communicative, scientific and methodical and projective.

Introduction of professional-mobile practice in educational process in the conditions of higher education institution promotes transition of future teachers from low - potentially non-mobile to high - potentially mobile (Iskhakov, 2015). 


\section{DISCUSSIONS}

In the course of experiment-searching work on identification and checking of the significance of pedagogical conditions of increasing the effectiveness of organizing and carrying out professional-mobile practice of students we succeeded to prove the following provisions:

- in the context of leading tendencies of development of the Russian system of social protection the professional mobility represents the dynamic quality of a person causing his success in professional activity to the changing conditions determined by objective changes of professional environment; ability to master innovations in the system of social protection, readiness for self-improvement, self-development and realization oneself in social and pedagogical activity and professional community, to self- transformation and transformation of the surrounding professional and living environment in the course of the activity;

- the concept of the Russian system of professional education defines the priority directions and the main reference points of professional pedagogical education in the course of which at future experts of social sphere the ability to reach compliance of their social and professional qualities to notions and requirements of the society is formed and developed, the active living position is implemented, person's professional mobility is formed;

- professional mobility formation as the quality of a social teacher personality in professional-pedagogical higher education institution becomes successful when realizing systemic, competence-based, axiological, activity approaches.

The following factors have conceptual value for targeted formation of teachers' professional mobility in the conditions of professional -mobile practice:

- creation of a system uniting all types the practices in complete unity as a component of continuous professional education (an administrative factor);

- formation of working programs contents of all types of practices including theoretical, scientific-research and activity components (a scientific-methodical factor);

- orientation of practice-oriented process to the formation at all subjects of education of value orientations and world view concepts meeting the requirements of dynamically developing and intensively changing world (an axiological factor);

- training of professionally mobile social teachers at the university is provided by system approach in organizing and carrying out the practice-oriented professional becoming of students as experts of social sphere on the basis of working out, introduction and permanent updating according to the changing educational purposes of the complex of interdependent working programs for practice;

- introduction of professional- mobile practice into educational process of professional- pedagogical higher education institution promotes transition of future experts from the lowest (elementary) to the highest (optimal) level of professional mobility.

\section{CONCLUSION}

Efficient realization of an applied bachelor degree is possible when arranging not only theoretical preparation of future-mobile social teachers in higher education institution, but also outside of higher education institution in the conditions of professional-mobile practice.

Professional-mobile practice of future social teachers in higher education institution represents purposely organized and controlled activity, based on the principles of interaction, mutual cooperation, and professional partnership of all practice participants.

The basis of modelling of professional -mobile practice of students in higher education institution as a complete system the principles of theoretical knowledge correlation and the actual picture of practical professional production activity of social organizations, the principle of stage-by-stage formation of professional competences at the student, production multiple variability of social -pedagogical situations, polyfunctionality and dynamism.

An important factor in realizing the applied nature of professional-mobile practice is project activity of the practice teacher himself directed to the solution of a particular social- pedagogical problem at people of different age groups and social categories in the conditions of institutions of various departmental affiliations. 


\section{RECOMMENDATIONS}

Materials of this article are of practical value for organizers of working practices of professional educational institutions.

The method of project activity will allow to strengthen the practice -oriented training of students for future professional activity in the conditions of practice.

\section{ACKNOWLEDGEMENT}

The work is performed according to the Russian Government Program of Competitive Growth of Kazan Federal University.

\section{REFERENCES}

Akishina, E. M., Sudakova, Y. E., Prokopyev, A. I., Yakubenko, K. Y., Solovyeva, N. A., \& Korzhuev, A. V. (2017). System of cultural experience development of humanities students in modern information media conditions. Man in India, 97(14), 115-127.

Amirova, L. A. (2009). Development of teacher's professional mobility in the system of extended education (Doctoral dissertation). Ufa.

Arkhangelskii, A. I. (2003). Professional mobility formation at students in the course of studying at technical colleges (PhD Thesis). Moscow.

Conics, O. A. (1997). The organization of pedagogical practice of students of pedagogical University in the course of vocational training of future teachers (PhD Thesis). Kurgan.

Davydova, N. N., Dorozhkin, E. M., \& Fedorov, V. A. (2018). Educational research networks principles of organization. International Journal of Engineering and Technology (UAE), 7(2), 24-29. https:// doi.org/10.14419/ijet.v7i2.13.11573

Davydova, N. N., Dorozhkin, E. M., Polyanskova, N. V., \& Nuykina, E. Y. (2016). Formation of a cluster integration system of educational institutions within the region. International Journal of Environmental and Science Education, 11(16), 9206-9221.

Drozdova, L. V. (2003). Formation of cognitive and professional independence of students in the course of pedagogical practice (PhD Thesis). Tambov.

Dzodziev, S. M. (2009). Pedagogical practice as the condition of development of students' research competences (PhD Thesis). Rostov on Don.

Efimova, S. A. (2017). Problems of competency-based assessment of applied qualifications. The Education and science journal, 19(5), 120-137. https:/ / doi.org/10.17853/1994-5639-2017-5-120-137

Evtodieva, T. E., Davydova, N. N., Videneeva, S. V., \& Fedorov, V. A. (2016). The concept of network organization and design of networks in logistics. International Journal of Economic Perspectives, 10(3), 75-82.

Galaguzova, M. A. (2016). Social pedagogics. Moscow: INFRA-M. https:/ / doi.org/10.12737/17214

Galaguzova, Yu. N. (2000). Structure and content of practice of the students studying at the specialiyu "social work". Ekaterinburg: Sava.

Gimaliev, V. G., Prokopev, A. I., Makarova, E. V., Abdulkhakova, K. R., Kozin, M. N., \& Fazylzyanova, G. I. (2018). Personality features and values orientations of university students with manipulative behavior. Espacios, 39(20), 14.

Gluzman, N. A. (2017). Professional image formation of a future social care teacher. The Education and science journal, 19(9), 52-69. https:/ / doi.org/10.17853/1994-5639-2017-9-52-69

Goryunova, L. V. (2006). Professional mobility of the expert as a problem of the developing education of Russia (PhD Abstract) Rostov on Don.

Gudzenko, B. Ya. (1987). Professional self-education of future teachers in the course of pedagogical practice (PhD Abstract). Moscow.

Igoshev, B. M. (2008). Organizational-pedagogical system of training of professionally mobile experts at pedagogical university: monography. Moscow: VLADOS.

Iskhakov, R. H. (2015). Assessment of effectiveness of professional and mobile practice of future social teachers. European journal of social sciences, 10, 253-263

Kalinovsky, Yu. I. (2001). Development of a social and professional mobility of an andragog in the context of sociocultural educational policy in the region (Doctoral dissertation). St. Petersburg. 
Kipina, O. A. (2009). Formation of professional and pedagogical mobility at students of pedagogical higher education institution (PhD Thesis). Ishim.

Kondrachuk, N. (2008). Working practice as formation factor of students' professional competence (PhD Thesis). Orenburg.

Korotkov, I. V. (2004). Pedagogical practice in the conditions of higher pedagogical education modernization (PhD Thesis). Moscow.

Kovalyova, A. G. (2001). Pedagogical conditions of the organization of the continuous pedagogical practice of social teachers on material of the college of All Russin child's center "Orlenok" (PhD Thesis). Rostov of Don, Russia, $193 \mathrm{p}$.

Kugel, S. A. (1983). Professional mobility in science. Moscow: Mysil.

Lavrentyeva, Z. I. (2014). Methodological problems of social and pedagogical phenomena research. Letters in an emission offline: online scientific magazine, 2, 1250.

Mardakhayev, L. V. (2013). Social pedagogics: the full course - textbook for bachelors. Moscow: YuRAYT.

Ministry of Education and Science of the Russian Federation of December 22, 2009 No. 788. (2009). Federal state standard of higher education in speciality 050400 Psychology and pedagogical education (the bachelor qualification (degree)): order of the Ministry of Education and Science of the Russian Federation of December 22, 2009 No. 788. Retrieved from http:/ / www.edu.ru/db-mon/mo/Data/d_10/prm200-1.pdf

Morozova, S. A., \& Symanyuk, E. E. (2012). Professional Mobility as the Realization Factor of Teacher's Innovative Activity. The Education and science journal, 4, 50-60. https:/ / doi.org/10.17853/1994-5639-2012-4-50-60

Moryleva, E. A. (2001). Development of social and professional mobility of students in the educational environment of higher education institution (PhD Thesis). Tobolsk.

Mutavchi, E. P., Prokopyev, A. I., Kostyleva, G. V., Blinov, L. V., Fedorov, V. V., \& Polichka, A. E. (2018). Scientific - methodical resource of student training and vocational motivation development in university. Espacios, $39(20), 15$.

Novikov, V. V. (2001). Professional mobility of technical colleges graduates in Russia at a turn of the 20-21st centuries (PhD Thesis). Moscow, Russia. https:/ / doi.org/10.1023/A:1010206918351

Reid-Griffin, A., \& Slaten, K.M. (2016). Wikis: Developing pre-service teachers'leadership skills and knowledge of content standards. European Journal of STEM Education, 1(1), 3-7. https:/ / doi.org/10.20897/lectito.201601

Slastenin, V. A. (1995). Social teacher: readiness for professional activity. Scientific works. Series psychology and pedagogical sciences. Moscow: MT of GU.

Sorokin, P. A. (1992). Person. Civilization. Society. Moscow: Politizdat.

The resolution of the Government of the Russian Federation. (2016). August 19, 2009 No. 667 “ On carrying out the experiment on creation of an applied bachelor degree in educational institutions of secondary technical school and higher education". Moscow: Government of the Russian Federation. 2009. Retrieved on 20.03.2018 from http:/ / www.garant.ru/products/ipo/prime/doc/96158/

Vasilenko, I. V. (1996). Sociocultural mobility as philosophical problem (PhD Abstract). Volgograd, Russia. 1996.

Zeer, E. F., Lebedeva, E. V., \& Zinnatova, M. V. (2016). Methodological bases of the implementation of the process and project approaches in vocational education. The Education and science journal, 7, 40-56. https:/ / doi.org/10.17853/1994-5639-2016-7-40-56

Zonina, N. A. (2009). Formation of professional and pedagogical abilities of students of engineering and pedagogical specialties in the course of pedagogical practice (PhD Thesis). Moscow.

\section{http://www.ejmste.com}

